\title{
The impact of sediment removal on the aquatic macroinvertebrate assemblage in a fishpond littoral zone
}

\author{
Jan SYCHRA* and Zdeněk ADÁMEK ${ }^{1)}$ \\ Department of Botany and Zoology, Faculty of Science, Masaryk University. Kotlářská 2, 61137 Brno, Czech Republic \\ ${ }^{1)}$ Faculty of Fisheries and Water Protection, University of South Bohemia, Zátiší 728/II, 38925 Vodňany, Czech Republic \\ * e-mail corresponding author: dubovec@seznam.cz
}

\begin{abstract}
Bottom sediment removal, a widely used technique in restoration management of standing water bodies, has a strong influence on communities of aquatic organisms. As most information on the impact of sediment removal on the aquatic environment comes from studies on lakes, the aim of this study was to describe macroinvertebrate assemblage succession in a fishpond (Štépánek fishpond, Bohemian-Moravian highlands, Czech Republic) littoral zone following restoration by sediment removal during the winter of 2003/2004. Semi-quantitative hand net sampling was undertaken one year before (2003) and in each of the following five years (2004-2008) after sediment removal. A significant decrease in both abundance (approx. 90\% of individuals) and diversity (approx. $30 \%$ of taxa) of macroinvertebrates was detected immediately after pond restoration. The values gradually increased over subsequent years, reaching comparable abundance and diversity three years after sediment removal. A significant shift was recorded in the taxonomic and functional composition of the macroinvertebrate assemblage after sediment removal. Mayfly larvae were the dominant invertebrates before restoration, while chironomid larvae and oligochaetes dominated after sediment removal. Phytophilous taxa, grazers and scrapers, and swimming or diving invertebrates were common in 2003, whilst open-water taxa preferring mud and other mostly inorganic microhabitats, gatherers/collectors, and burrowing/boring invertebrates were relatively common after sediment removal. In 2008, the assemblage reverted towards the situation before sediment removal, probably connected with a lower water level and accelerated macrophyte bed succession. Principal Component Analysis on the species data confirmed the differences in invertebrate taxonomic structure among sampling years. Succession of the fishpond invertebrate assemblage in the years following sediment removal was mainly influenced by fish farming practice and local conditions, i.e. the presence of macrophyte beds, mesohabitat changes following restoration, and the presence of other water bodies in the surroundings.
\end{abstract}

Key words: fishpond, restoration, macroinvertebrates, succession, biodiversity, functional groups

\section{INTRODUCTION}

Eutrophic and hypertrophic lakes and ponds require specific management to conserve their main functions, usually involving biomanipulation, drainage or sediment removal. Sediment removal is a common technique in restoration management of standing water bodies around the world. It is used particularly in lakes and ponds with considerable sediment accumulation (especially in areas of soil and nutrient runoff due to inappropriate agricultural land use) in order to reduce internal nutrient loading and for general restoration of the aquatic ecosystem (Moss et al. 1986, 1996; Boyd 1995; Pokorný \& Hauser 2002; Clemente et al. 2005; Ayala et al. 2007).

Sediment removal influences both the water body environment and its communities of aquatic organisms. This technique has a proven positive impact on water quality (Pokorný \& Hauser 2002) and on reduction of phosphorus released from sediment (Moss et al. 1986; Phillips et al. 1999; Søndergaard et al. 2000), chlorophyll- $a$ and blooms of cyanobacteria (Moss et al. 1996; Pokorný \& Hauser 2002). It also results in increases in phytoplankton diversity (Poulíčková et al. 1998;
Pokorný \& Hauser 2002), increases in the Daphnia population (Moss et al. 1996) and the re-establishment of aquatic macrophytes generally (Brouwer et al. 2002; Van Wichelen et al. 2007). In the majority of cases, however, these effects have been only short-term.

On the other hand, negative impacts of sediment removal have also been documented. The displacement of large amounts of sediment has a strong negative influence on populations of animals that are associated with sediments during their life cycle, such as the medicinal leech Hirudo medicinalis (Schenková et al. 2009) or aquatic turtles and salamanders (Aresco \& Gunzburger 2004). These are often removed at the same time as the sediment by heavy machinery. Oberholster et al. (2007) described unfavourable succession following restoration through sediment removal and artificial mixing of an urban lake in North America. Post restoration, the lake suffered from cyanobacterial blooms and there was a decrease in the Daphnia population.

In general, very little is known about the impact of sediment removal on littoral aquatic invertebrate assemblages. A decrease in both the diversity and density of littoral invertebrates in the season following such inter- 


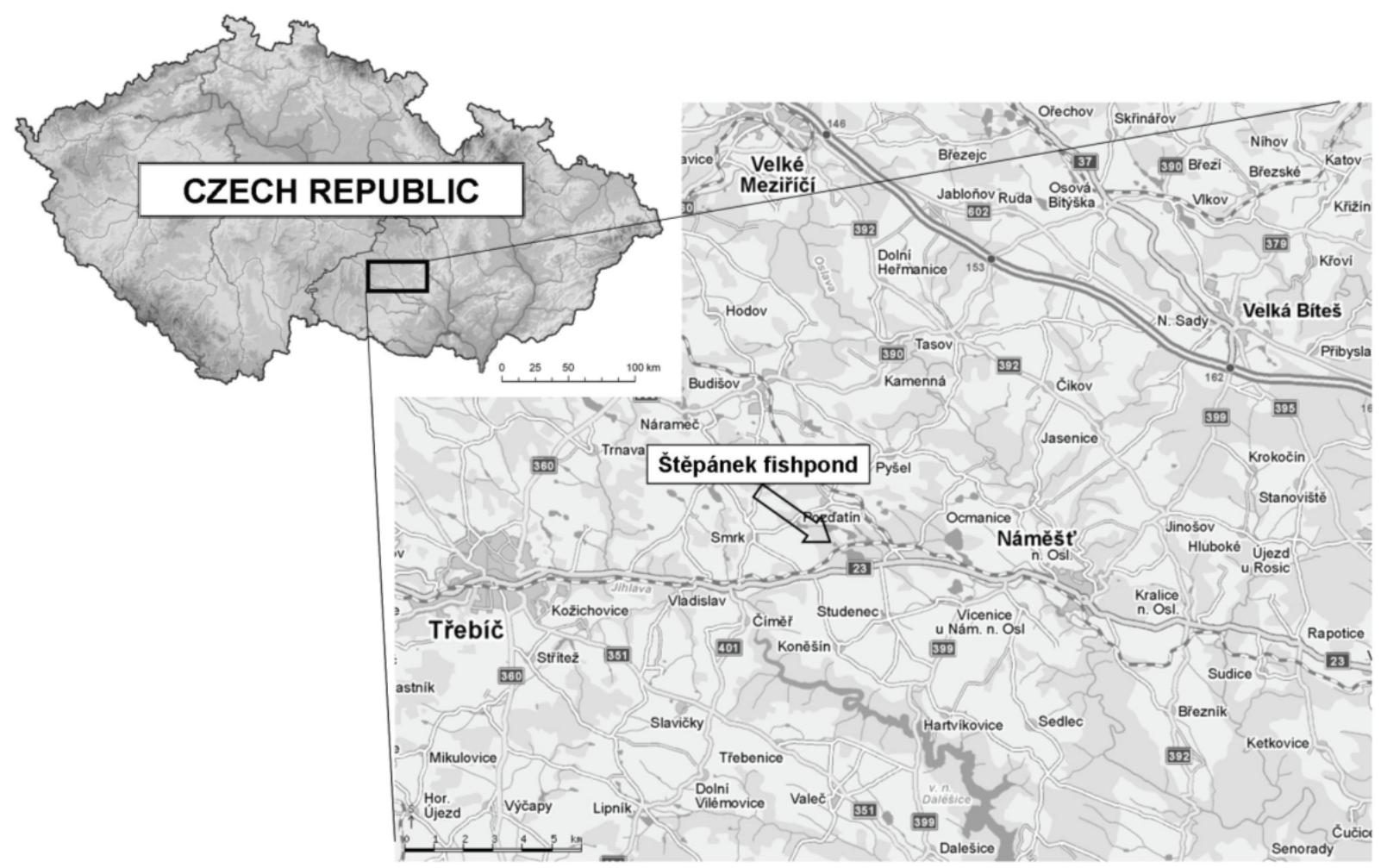

Fig. 1. Location of the Štěpánek fishpond in the Czech Republic (www.mapy.cz).

vention, however, has been documented in central Florida by Butler et al. (1992) and in Colorado by Oberholster et al. (2007).

Most information available on the impact of sediment removal on aquatic ecosystems relates to studies on lakes. In fishponds that are constructed primarily for aquacultural purposes, sediment removal is the most logical solution for reduction of internal loading (Hejný \& Husák 1978; Björk 1988; Brönmark \& Hansson 2005), and is commonly associated with increasing the pond fish farming capacity for subsequent years (Boyd 1995). Research on the impact of such intervention on the fishpond aquatic biota is still scanty. The aim of this study, therefore, is to describe aquatic macroinvertebrate succession in the littoral zone of a small fishpond following restoration through sediment removal.

\section{MATERIAL AND METHODS}

The Štěpánek fishpond is situated in the eastern part of the Bohemian-Moravian highlands (Fig. 1; GPS $49^{\circ} 13^{\prime} 24^{\prime \prime} \mathrm{N}, 16^{\circ} 02^{\prime} 24^{\prime \prime E}$ ) at an altitude of $450 \mathrm{~m}$ a.s.1. This small fishpond (2.2 ha) has one small inflow, though it is almost exclusively supplied with water through precipitation. The pond, which is surrounded by woodland and meadow, has been exploited for fish farming for decades and is usually emptied for a short period only during the yearly autumn pond harvest. Vegetation over most of the pond littoral zone was well developed and dominated by narrow-leaf cattail (Typha angustifolia) and reed sweetgrass (Glyceria maxima). In
2003, semi-quantitative sampling of littoral aquatic macroinvertebrates was undertaken as a control. During the winter of 2003/2004, the pond was drained completely and the accumulated sediment removed using heavy machinery, i.e. bulldozers removed the organic sediment to a depth of about $1 \mathrm{~m}$ and this was loaded onto trucks and carried away. The littoral macrophyte beds were almost completely destroyed. From 2005 on, the pond was stocked with high numbers of common carp (Cyprinus carpio), tench (Tinca tinca), grass carp (Ctenopharyngodon idella) and zander (Sander lucioperca). In order to document changes in the macroinvertebrate assemblage following restoration, sampling continued each year between 2004 and 2008.

Sampling always took place in the middle of July, following the same methodology adopted in 2003. Each year, macroinvertebrates were collected via a five-minute sweep with a hand net through the macrophyte stems and the upper layer of sediment along a comparable peripheral distance of approximately $200 \mathrm{~m}$ (about $30 \%$ of the pond perimeter). A hand net with a $500 \mathrm{~mm}$ mesh size was used as this is deemed suitable for the sampling of littoral macroinvertebrates in emergent vegetation (García-Criado \& Trigal 2005; Sychra \& Adámek 2010). The sampling site was located along the western, shallow bank of the pond, where macrophyte beds were well developed in 2003. Samples were preserved in $4 \%$ formaldehyde solution. In the laboratory, macroinvertebrates were determined to the lowest possible taxonomic level. 
Tab. 1. Definition of microhabitats, feeding groups and type of locomotion used in the analyses and their representatives according to the Asterics software (AQEM consortium 2008).

\begin{tabular}{|c|c|c|}
\hline Term & Definition & Representatives \\
\hline Microhabitat pelal & mud; grain size $<0.063 \mathrm{~mm}$ & some tubificids, some aquatic beetles, some chironomids \\
\hline Microhabitat argyllal & silt, loam, clay; grain size $<0.063 \mathrm{~mm}$ & some oligochaetes, some chironomids \\
\hline Microhabitat psammal & sand; grain size $0.063-2 \mathrm{~mm}$ & some tubificids, some chironomids \\
\hline Microhabitat akal & fine to medium-sized gravel; grain size $0.2-2 \mathrm{~cm}$ & some oligochaetes, some chironomids \\
\hline Microhabitat lithal & coarse gravel, stones, boulders; grain size $>2 \mathrm{~cm}$ & some leeches, some Diptera \\
\hline Microhabitat phytal & $\begin{array}{l}\text { algae, mosses and macrophytes including living } \\
\text { parts of terrestrial plants }\end{array}$ & $\begin{array}{l}\text { aquatic snails, naidids, some leeches, mayfly nymphs, some } \\
\text { water bugs, some aquatic beetles, some Diptera }\end{array}$ \\
\hline Microhabitat POM & $\begin{array}{l}\text { particulate organic matter, such as woody debris, } \\
\text { CPOM, FPOM }\end{array}$ & $\begin{array}{l}\text { some oligochaetes, some water bugs, some dragonfly } \\
\text { nymphs, some aquatic beetles, some chironomids }\end{array}$ \\
\hline Grazers and scrapers & $\begin{array}{l}\text { feeders on endo- and epilithic algal tissues, biofilm, } \\
\text { partially POM and tissues of living plants }\end{array}$ & $\begin{array}{l}\text { aquatic snails, some naidids, mayfly nymphs, some } \\
\text { chironomids }\end{array}$ \\
\hline Gatherers/collectors & feeders on sedimented FPOM, detritus & $\begin{array}{l}\text { oligochaetes, mayfly nymphs, some water bugs, some } \\
\text { chironomids, some Diptera }\end{array}$ \\
\hline Predators & feeders on live prey & $\begin{array}{l}\text { some leeches, some water bugs, dragonfly nymphs, some } \\
\text { aquatic beetles, some chironomids, some Diptera }\end{array}$ \\
\hline Swimming/diving & actively moving in water column & $\begin{array}{l}\text { naidids, some mayfly nymphs, water bugs, some aquatic } \\
\text { beetles, some Diptera }\end{array}$ \\
\hline Sprawling/walking & actively moving on substrates & $\begin{array}{l}\text { aquatic snails, naidids, leeches, dragonfly nymphs, some } \\
\text { aquatic beetles, some chironomids, some Diptera }\end{array}$ \\
\hline $\begin{array}{l}\text { Burrowing/boring } \\
\text { (semi) Sessil }\end{array}$ & $\begin{array}{l}\text { making a hole or tunnel dug into the ground } \\
\text { permanently attached to substrate }\end{array}$ & $\begin{array}{l}\text { some oligochaetes, some chironomids, some Diptera } \\
\text { some oligochaetes, some leeches, some chironomids }\end{array}$ \\
\hline
\end{tabular}

Tab. 2. Main characteristics of the littoral macroinvertebrate assemblage, macrophyte beds, fish stock and water level at the Štěpánek fishpond during the years 2003-2008. Note: Joint taxa = percentage of taxa occurring before sediment removal recorded afterwards; Eudominant groups $=$ taxa with relative abundances higher than $10 \%$; Macrophyte beds $=$ relative proportion of the pond perimeter comprising macrophyte beds; Fish species and age: $\mathrm{C}=$ common carp, $\mathrm{GC}=$ grass carp, $\mathrm{T}=$ tench, $\mathrm{Z}=\mathrm{zander}, 1-3$ $=$ fish age in years; Usual water level = water level in fully filled pond).

\begin{tabular}{|c|c|c|c|c|c|c|}
\hline & 12.7 .2003 & 20.7 .2004 & 16.7.2005 & 18.7.2006 & 21.7 .2007 & 12.7.2008 \\
\hline No. of individuals & 3499 & 346 & 927 & 3349 & 2072 & 1186 \\
\hline No. of taxa & 44 & 32 & 33 & 41 & 21 & 48 \\
\hline Joint taxa $(\%)$ & 100 & 38.6 & 50.0 & 52.3 & 25.0 & 45.5 \\
\hline \multirow[t]{3}{*}{ Eudominant groups (more than $10 \%$ ) } & Ephemeroptera & Chironomidae & Chironomidae & Oligochaeta & Oligochaeta & Heteroptera \\
\hline & Heteroptera & Oligochaeta & Hydrachnellae & Ephemeroptera & Heteroptera & Chironomidae \\
\hline & Hirudinida & & Oligochaeta & & Chironomidae & Ephemeroptera \\
\hline Macrophyte beds (\%) & 28.9 & 3.4 & 16.7 & 11.0 & 5.0 & 28.5 \\
\hline Dominant macrophytes & $\begin{array}{l}\text { Typha angustifolia } \\
\text { Glyceria maxima } \\
\text { Schoenoplectus sp. }\end{array}$ & $\begin{array}{l}\text { species of exposed } \\
\text { bottoms } \\
\text { Glyceria maxima }\end{array}$ & $\begin{array}{c}\text { Phalaris arundinacea } \\
\text { Typha latifolia } \\
\text { Glyceria maxima }\end{array}$ & $\begin{array}{l}\text { Glyceria maxima } \\
\text { Typha latifolia }\end{array}$ & $\begin{array}{l}\text { Glyceria maxima } \\
\text { Typha latifolia }\end{array}$ & $\begin{array}{l}\text { Typha latifolia } \\
\text { Glyceria maxima }\end{array}$ \\
\hline Fish stock (kg.ha-1) & 180.0 & 0.0 & 965.0 & 973.9 & 835.2 & 870.0 \\
\hline Fish species and age & $\mathrm{C} 2$ & 0 & $\mathrm{C} 2, \mathrm{GC} 3$ & $\mathrm{C} 1-2, \mathrm{~T} 1, \mathrm{Z} 1$ & $\mathrm{C} 2, \mathrm{~T} 2$ & $\mathrm{C} 2, \mathrm{~T} 2, \mathrm{GC} 1, \mathrm{Z} 1$ \\
\hline Difference from usual water level & 0 & 0 & 0 & 0 & $-1 \mathrm{~m}$ & $-0.75 \mathrm{~m}$ \\
\hline
\end{tabular}

At each sampling, the rate of aquatic vegetation succession (dominant macrophyte taxa, proportion of macrophyte beds on the pond perimeter) and water level were also monitored. Data on fish stock (see Tab. 2) were provided by the local fish farming association (MO MRS Náměšt' nad Oslavou).

Principal Component Analysis (PCA) was employed to identify the most important gradients in the species data. Environmental data were fitted ex-post to the PCA ordination axes as passive variables. Both analyses and graphs were produced using Canoco for Windows (Version 4.5; ter Braak \& Šmilauer 2002) and Microsoft Excel. All taxa were assigned to feeding and microhabitat preference groups using Asterics software (version 3.1.1; AQEM consortium 2008; Tab. 1).

\section{RESULTS}

The littoral habitats of the Štěpánek fishpond were markedly disturbed by the sediment removal in the winter of 2003/2004. During these operations, the beds of narrow-leaf cattail and reed sweetgrass were destroyed; only very restricted beds of reed sweetgrass and vegetation of the exposed fishpond bottoms being recorded inside and along the pond edge in 2004. Restoration of the macrophyte beds was very slow over subsequent years. Following a hot and dry summer in 2007, however, water level was low and macrophyte succession accelerated. In 2008, reed sweetgrass and broadleaf cattail (Typha latifolia) beds were well developed and were comparable to 2003 (Tab. 2).

Altogether, more than 11000 individuals of 99 macroinvertebrate taxa were recorded between the years 2003 and 2008 (see Appendix 1). The highest abundance (3 499 individuals) and second highest taxa richness (44 taxa) were recorded in 2003, before sediment removal. After intervention, a significant decrease in both abundance and diversity was recorded, amounting to 346 individuals and 32 taxa, respectively. Total 
Tab. 3. Total abundance of higher taxa, number of lower taxa and relative abundance of temporal (aquatic insects) and permanent (gastropods, oligochaetes, leeches, crustaceans and water mites) fauna.

\begin{tabular}{lcccccc}
\hline & 2003 & 2004 & 2005 & 2006 & 2007 & 2008 \\
\hline \multirow{7}{*}{ Gastropoda } & $245 / 3$ & $5 / 2$ & $25 / 2$ & $84 / 3$ & $0 / 0$ & $111 / 2$ \\
Oligochaeta & $347 / 5$ & $70 / 6$ & $159 / 5$ & $1872 / 5$ & $1048 / 5$ & $13 / 3$ \\
Hirudinida & $377 / 5$ & $1 / 1$ & $6 / 2$ & $154 / 4$ & $8 / 1$ & $6 / 3$ \\
Hydrachnellae & $22 / 1$ & $10 / 1$ & $212 / 1$ & $334 / 1$ & $4 / 1$ & $66 / 1$ \\
Ephemeroptera & $1915 / 2$ & $10 / 2$ & $19 / 2$ & $392 / 2$ & $0 / 0$ & $272 / 2$ \\
Heteroptera & $430 / 6$ & $15 / 4$ & $13 / 4$ & $240 / 6$ & $788 / 5$ & $347 / 10$ \\
Chironomidae & $120 / 10$ & $228 / 11$ & $451 / 9$ & $224 / 10$ & $212 / 6$ & $322 / 12$ \\
Others & $43 / 13$ & $7 / 6$ & $42 / 9$ & $47 / 11$ & $12 / 4$ & $49 / 16$ \\
\hline & \multicolumn{7}{c}{ Number of individuals / number of taxa } \\
Permanent & 28.35 & 24.86 & 43.37 & 73.24 & 51.16 & 16.53 \\
Temporal & 71.65 & 75.14 & 56.63 & 26.76 & 48.84 & 83.47 \\
\hline
\end{tabular}

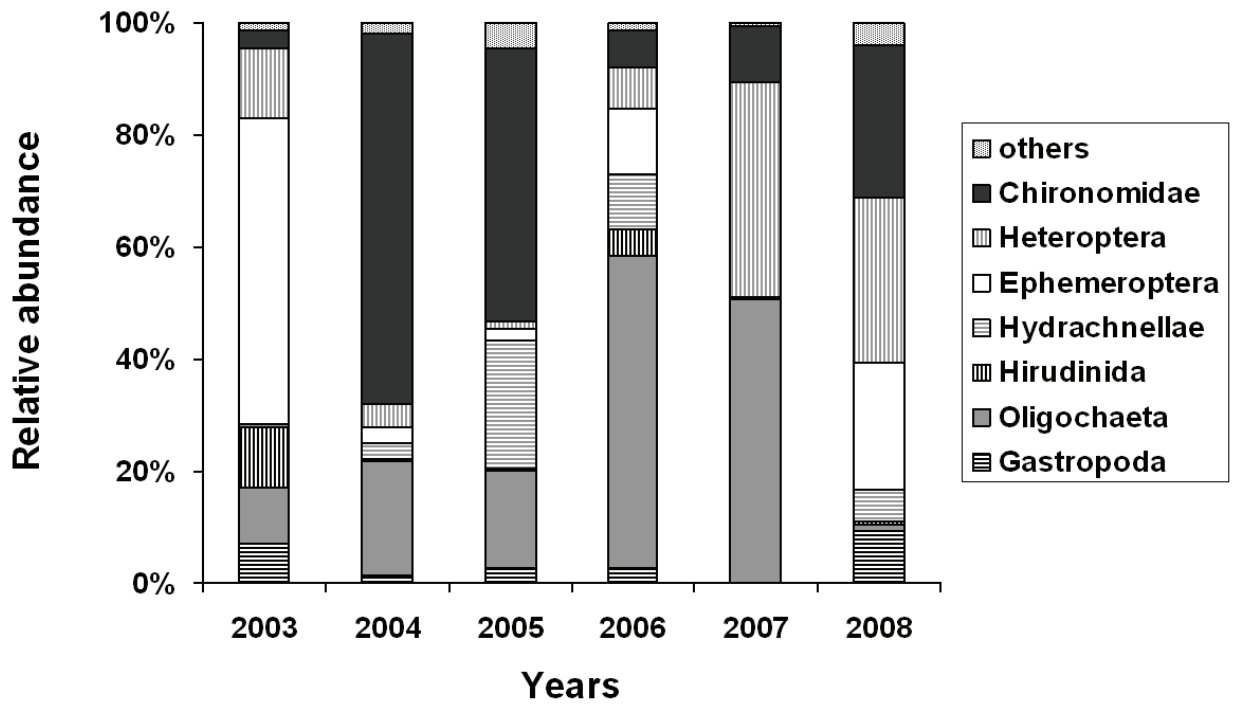

Fig. 2. Relative abundance of higher macroinvertebrate taxa.

macroinvertebrate abundance was approximately 10 times lower in 2004. Over the next two years (20052006), abundance increased again to 3349 individuals (41 taxa) by 2006, but was followed by a second decline over 2007-2008 (Tab. 2). The number of invertebrate taxa fluctuated between sampling years. While a decrease in number of taxa was detected immediately following pond restoration, values comparable with 2003 were found in 2006 and 2008 (Tab. 2).

A significant shift in assemblage composition was recorded following sediment removal. Mayfly larvae (mainly Cloeon dipterum) were the dominant invertebrates in 2003, while chironomid larvae (e.g., Cricotopus gr. sylvestris, Glyptotendipes sp. or Microtendipes gr. chloris) dominated in 2004-2005 and oligochaetes (e.g., Ophidonais serpentina, Stylaria lacustris, Dero digitata or Limnodrilus sp.) in 2006-2007. A relatively balanced assemblage was documented in 2008, with mayfly nymphs, aquatic bugs (mainly Corixidae) and chironomid larvae as the dominant macroinvertebrate groups (Tab. 3; Fig. 2).
A shift in the invertebrate assemblage was also evident as regards functional grouping. Phytophilous taxa, grazers and scrapers, and swimming or diving invertebrates were common in 2003. The abundances of these groups decreased strongly in the years following sediment removal, with taxa preferring mud (pelal) and other mostly inorganic microhabitats (argyllal, psammal, akal, and lithal), gatherers/collectors, and burrowing/boring invertebrates being relatively more common following sediment removal (Fig. 3). In 2008, a decline in the abundance of these taxa and a new increase in the relative number of grazers and scrapers was recorded. The ratio between abundances of permanent and temporal taxa remained unchanged after pond restoration. In most years, aquatic insects (temporal fauna) were more abundant; aquatic snails, oligochaetes and leeches (permanent fauna) only being more abundant in the years 2006-2007 (Tab. 3).

Species-data based PCA confirmed differences in the taxonomic structure of the invertebrate assemblage between the sampling years described. The first PCA 

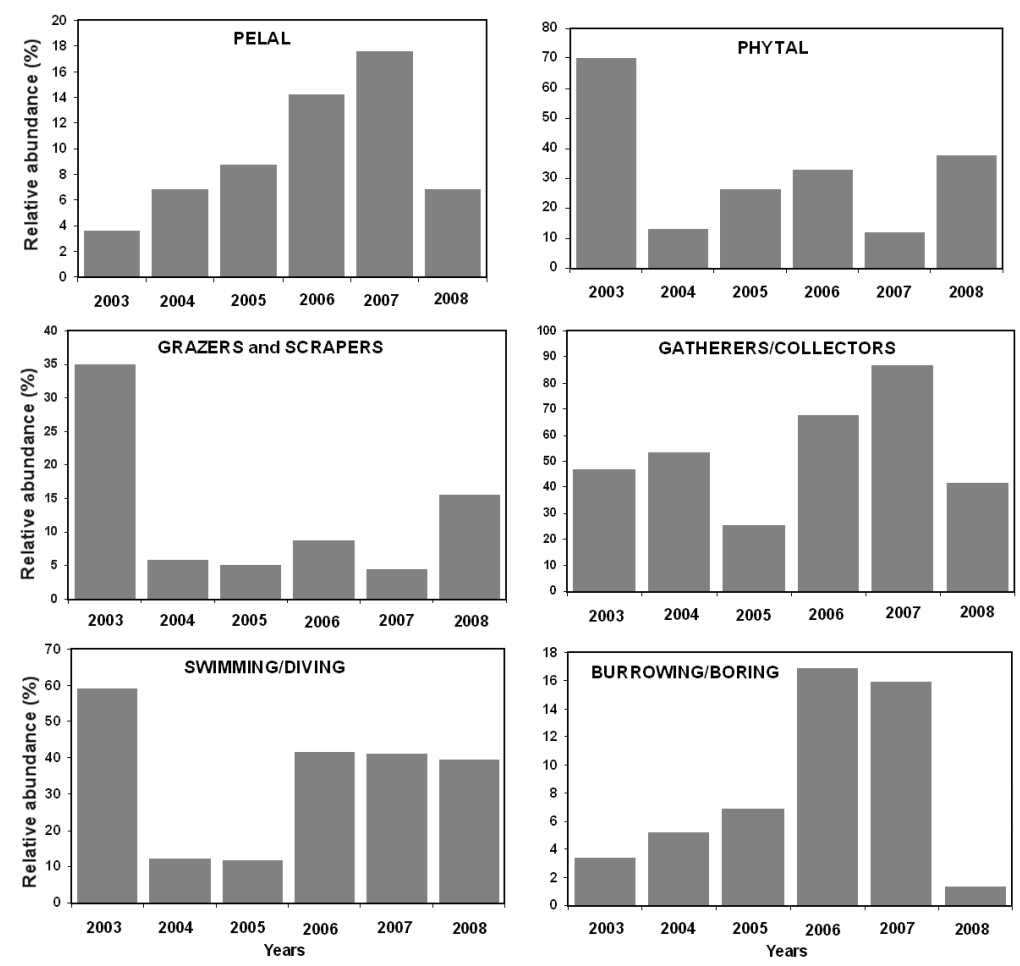

Fig. 3. Relative abundance of the main functional invertebrate groups based on microhabitat and food preference and type of movement.

axis explained $63.1 \%$ of total variance, and the second axis $25.3 \%$. In 2003 , before sediment removal, phytophilous taxa such as the mayfly Cloeon dipterum, the snail Gyraulus albus or leeches such as Hemiclepsis marginata and Helobdella stagnalis were the dominant invertebrates. Chironomid larvae and oligochaetes were more common in 2004-2005 and 2006-2007, respectively. Finally, in 2008, the corixids Micronecta scholtzi and Sigara falleni and the snail Radix auricularia were most abundant (Fig. 4). The sample scores on the first PCA axis were strongly positively correlated with the occurrence of phytal preferring taxa, grazers and scrapers, and sprawling/walking invertebrates; while the occurrence of burrowing/boring invertebrates and gatherers/collectors was positively correlated with the second axis (Fig. 5).

\section{DISCUSSION}

Aquatic macroinvertebrates living in fishpond littoral zones are a very important link in the pond food chains. Such invertebrates display life strategies that enhance long-term survival in rapidly changeable pond littoral conditions (Ward 1992; Dvořák \& Imhof 1998). During sediment removal operations, littoral macrophyte beds and the upper layer of organic sediment, which represent important habitats for phytophilous and bottom-dwelling macroinvertebrates, are completely destroyed and/or removed. Moreover, the upper sediment layer contains the greater part of the plant and invertebrate egg bank, from which the restored sites would normally be recolonised (Combroux et al. 2002; Gleason et al. 2004). Invertebrate recolonisation following sediment removal, therefore, would be comparable with the relatively rapid colonisation of a newly created water body, where most taxa appear during the first season, followed by a decrease in diversity and the dominance of a few taxa only in subsequent seasons (Solimini et al. 2003; Ruhí et al. 2009). Indeed, Butler et al. (1992) observed high invertebrate diversity in the second year after sediment removal from a lake in Florida, USA, and a rapid decrease the following season. The results of such studies, however, are in opposition with the results of our research.

Our results indicate that both the diversity and abundance of littoral invertebrates in the Štěpánek fishpond decreased strongly after sediment removal (by about $90 \%$ of individuals and $30 \%$ of taxa) and gradually increased again over subsequent years. The differences in the response of invertebrate assemblages observed is probably due to differences between the conditions found in natural lakes and the semi-natural conditions prevalent in fishponds, where fish farming management practices have a considerable influence on the continuity of natural succession. According to previous studies, early colonisers, such as chironomid larvae (Danell \& Sjöberg 1982; Layton \& Voshell 1991; Butler et al. 1992; Brown et al. 1997; Solimini et al. 2003) are the most abundant group in the two years following sediment removal; the rapid colonisation of aquatic bugs and beetles, which are usually among the first colonisers 


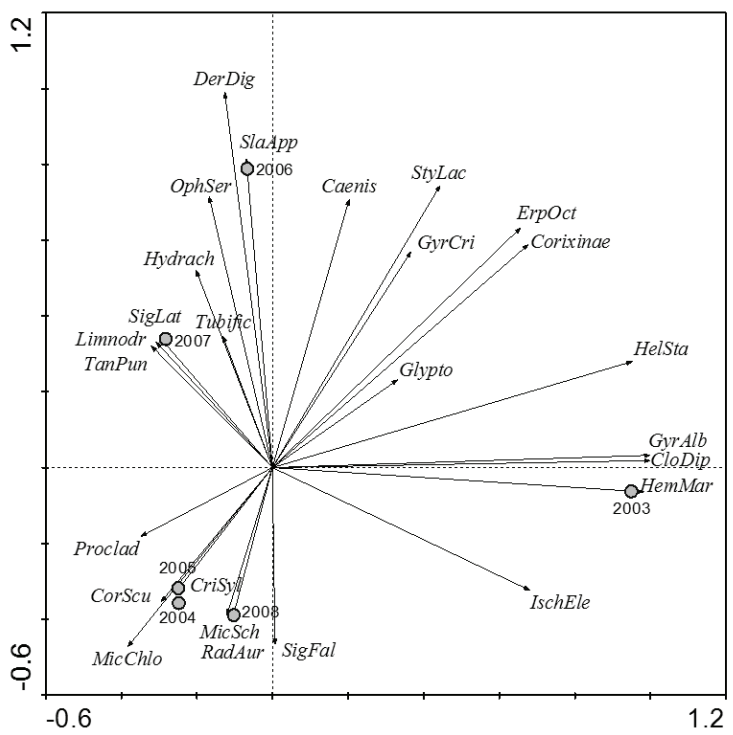

Fig. 4. PCA ordination plot with samples and most abundant macroinvertebrate taxa (more than 40 captured individuals). For species codes see Appendix.

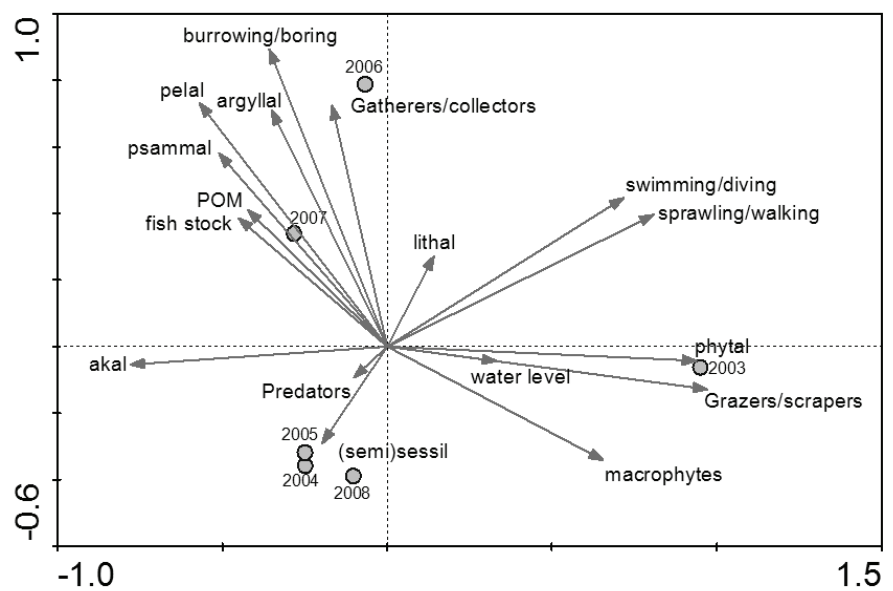

Fig. 5. PCA ordination plot with samples, monitored factors (macrophytes, fish stock, water level) and functional macroinvertebrate groups (according to Asterics software).

(Popham 1964; Danell \& Sjöberg 1982; Layton \& Voshell 1991; Jeffries 1994), being inhibited by high fish stock and the absence of macrophytes.

The relatively balanced ratio between temporal and permanent fauna before and after sediment removal, as well as the presence of approximately half the previous permanent taxa (gastropods, oligochaetes) suggests that their eggs or cocoons were not completely removed with the sediments as such taxa are usually slow to colonise new sites (Danell \& Sjöberg 1982; Brown et al. 1997). The presence of other water bodies in the surrounding area plays an important role for recolonisation of such taxa (Barnes 1983; Brady et al. 2002) and such could well be the case for the Štěpánek pond, which is located within a system of nearby fishponds.

The absence of littoral macrophytes, and their subsequent gradual development, appeared to be the most important factor influencing invertebrate assemblage succession following sediment removal at the study site. Due to their structural complexity and importance as a substrate for periphyton, macrophyte beds serve both as living space and as a refuge against fish predation for many aquatic invertebrates. Their presence in the littoral zone, therefore, greatly increases invertebrate diversity (Dvořák \& Imhof 1998; Petr 2000; Solimini et al. 2003). Sediment removal at the Štěpánek pond resulted in a decrease in both abundance and diversity of a number of groups usually associated with macrophyte beds, with the greatest negative impact being recorded in grazers and scrapers (e.g., some snails), phytal preferring taxa (e.g., snails, some leeches, mayfly nymphs, aquatic bugs and beetles, some dipterans) and actively swimming/diving invertebrates (e.g., aquatic bugs and beetles). Oberholster et al. (2007) similarly recorded a decline in scrapers and shredders (especially isopods and caddis fly larvae) after removal of lake bottom 
sediment in Colorado. In the years following restoration, constantly high water level and high stock with grass carp were probably important factors negatively influencing aquatic macrophyte bed regeneration in the Štěpánek pond, a process described in detail by Hroudová \& Zákravský (1999) and Zákravský \& Hroudová (2007).

In general, functional and taxonomic shifts in the macroinvertebrate assemblage were connected with changes in the littoral habitat of the pond. Sediment removal changes both the physical and chemical characteristics of the bottom soil (Yuvanatemiya \& Boyd 2006); restored sites tending to have more inorganic substrates and/or bottom lacking in macrophytes as compared with undisturbed sites with more vegetation and organic matter (Hejný \& Husák 1978; Butler et al. 1992). At the Štěpánek pond, the relative abundance of invertebrates preferring pelal and some inorganic substrates and burrowing/boring taxa (especially some oligochaetes and chironomid larvae) gradually increased in the years after sediment removal. A similar shift from phytophilous to more open-water taxa was also documented under natural conditions by Oberholster et al. (2007) for invertebrates and Tugend \& Allen (2004) for fish assemblages, following restoration of a lake littoral zone.

Invertebrate assemblage succession in the five years following sediment removal was also influenced by variations in local conditions. For example, the development of littoral vegetation was accelerated by lower water level in 2007. Subsequently, by 2008 , the macrophyte beds had re-established to level existing before pond restoration (as found by Hroudová \& Zákravský 1999). Similarly, the relative abundances of phytophilous invertebrates and grazers and scrapers had also increased and the relative abundances of pelal preferring invertebrates and burrowing/boring taxa decreased. Such relatively rapid changes in the pond ecosystem indicate an unsteady state for aquatic plant and invertebrate assemblages in pond littoral zones. In general, we can conclude that macroinvertebrate abundances in fishpond littorals can change year-by-year due to both specific management intervention and local environmental conditions. On the other hand, assemblage diversity is also significantly related to taxa composition in the previous year (see Brady et al. 2002).

This pilot study demonstrated several shortcomings. Future research on the impact of sediment removal on fishpond littoral macroinvertebrate assemblages must be supported by more detailed sampling during the growing season and by monitoring of changes in physical and chemical conditions at the micro- and mesohabitat levels. Further detailed research is also recommended on the complex impact of sediment removal on aquatic macrophytes, macrozoobenthos and zooplankton in fishponds. Results of this and similar studies are important, especially in connection with management measures on carp fishponds, as they bring fish farming issues into closer harmony with the conservation of threatened wetland ecosystems, and vice versa.

\section{ACKNOWLEDGEMENT}

We thank Jana Nerudová and Karla Petřivalská for their help with chironomid larvae and oligochaetes determination. This study was supported by the Ministry of Education of the Czech Republic (projects nos MSM 0021622416 and CENAKVA CZ.1.05/2.1.00/01.0024).

\section{REFERENCES}

AQEM Consortium. 2008. ASTERICS: AQEM/STAR Ecological River Classification System, Version 3.1.1. http://www.fliessgewaesserbewertung.de/download/berech nung/.

Aresco, M.J. \& M.S. Gunzburger. 2004. Effects of large-scale sediment removal on herpetofauna in Florida wetlands. $J$. Herpetol., 38: 275-279.

Ayala, R., F. Acosta, W.M. Mooij, D. Rejas \& P.A. Van Damme. 2007. Management of Laguna Alalay: a case study of lake restoration in Andean valleys in Bolivia. Aquat. Ecol., 41: 621-630.

Barnes, L.E. 1983. The colonization of ball-clay ponds by macroinvertebrates and macrophytes. Freshwat. Biol., 13: 561-578.

Björk, S. 1988. Redevelopment of lake ecosystems. A case study report approach. Ambio, 17: 90-98.

Boyd, C.E. 1995. Bottom Soils, Sediment and Pond Aquaculture. Chapman and Hall, New York: 350 pp.

Brady, V.J., B.J. Cardinale, J.P. Gathman \& T.M. Burton. 2002. Does facilitation of faunal recruitment benefit ecosystem restoration? An experimental study of invertebrate assemblages in wetland mesocosms. Restor. Ecol., 10: 617-626.

Brönmark, Ch. \& L.A. Hansson. 2005. The Biology of Lakes and Ponds. Oxford University Press: 285 pp.

Brouwer, E., R. Bobbink \& J.G.M. Roelofs. 2002. Restoration of aquatic macrophyte vegetation in acidified and eutrophied softwater lakes: an overview. Aquat. Bot., 73: 405-431.

Brown, S.C., K. Smith \& D. Batzer. 1997. Macroinvertebrate responses to wetland restoration in northern New York. Environ. Entomol., 26: 1016-1024.

Butler, R.S., E.J. Moyer, M.W. Hulon \& V.P. Williams. 1992. Littoral zone invertebrate communities as affected by a habitat restoration project on Lake Tohopekaliga, Florida. J. Freshwat. Ecol., 7: 317-328.

Clemente, J. M., N. Mazzeo, J. Gorga \& M. Meerhoff. 2005. Succession and collapse of macrozoobenthos in a subtropical hypertrophic lake under restoration (Lake Rodó, Uruguay). Aquat. Ecol., 39: 455-464.

Combroux, I.C.S., G. Bornette \& C. Amoros. 2002. Plant regenerative strategies after a major disturbance: the case of a riverine wetland restoration. Wetlands, 22: 234-246.

Danell, K. \& K. Sjöberg. 1982. Successional patterns of plants, invertebrates and ducks in a man-made lake. $J$. Appl. Ecol., 19: 395-409.

Dvořák, J. \& G. Imhof. 1998. The role of animals and animal communities in wetlands. In: D.F. Westlake, J. Květ \& A. Szczepański (Eds), The Production Ecology of Wetlands, The IBP Synthesis. Cambridge University Press: 211-318.

García-Criado, F. \& C. Trigal. 2005. Comparison of several techniques for sampling macroinvertebrates in different habitats of a North Iberian pond. Hydrobiologia, 545: 103-115.

Gleason, R.A., N.H. Euliss, D.E. Hubbard \& W.G. Duffy. 2004. Invertebrate egg banks of restored, natural, and 
drained wetlands in the prairie pothole region of the United States. Wetlands, 24: 562-572.

Hejný, S. \& Š. Husák. 1978. Ecological Effects of Fishpond Amelioration. In: D. Dykyjová \& J. Květ (Eds), Pond Littoral Ecosystems, Structure and Functioning, Ecological Studies, Vol. 28. Springer-Verlag, Berlin, Heidelberg, New York: 113-125.

Hroudová, Z. \& P. Zákravský. 1999. Vegetation dynamics in a fishpond littoral related to human impact. Hydrobiologia, 415: 139-145.

Jeffries, M. 1994. Invertebrate communities and turnover in wetland ponds affected by drought. Freshwat. Biol., 32: 603-612.

Layton, R.J. \& J.R. Voshell Jr. 1991. Colonization of new experimental ponds by benthic macroinvertebrates. Environ. Entomol., 20: 110-117.

Moss, B., H. Balls, K. Irvine \& J. Stansfield. 1986. Restoration of two lowland lakes by isolation from nutrient-rich water sources with and without removal of sediment. $J$. Appl. Ecol., 23: 391-414.

Moss, B., J. Stansfield, K. Irvine, M. Perrow \& G. Phillips. 1996. Progressive restoration of a shallow lake: a 12-year experiment in isolation, sediment removal and biomanipulation. J. Appl. Ecol., 33: 71-86.

Oberholster, P.J., A.M. Botha \& T.E. Cloete. 2007. Ecological implications of artificial mixing and bottom-sediment removal for a shallow urban lake, Lake Sheldon, Colorado. Lake Reserv. Manage., 12: 73-86.

Petr, T. 2000. Interactions between fish and aquatic macrophytes in inland waters. A review. FAO Fisheries Technical Paper, no. 396. FAO, Rome: 185 pp.

Phillips, G., A. Bramwell, J. Pitt, J. Stansfield \& M. Perrow. 1999. Practical application of 25 years' research into the management of shallow lakes. Hydrobiologia, 395/396: 61-76.

Pokorný, J. \& V. Hauser. 2002. The restoration of fish ponds in agricultural landscapes. Ecol. Eng., 18: 555-574.

Popham, E.J. 1964. The migration of aquatic bugs with special reference to the Corixidae (Hemiptera Heteroptera). Arch. Hydrobiol., 60: 450-496.

Poulíčková, A., L. Pechar \& M. Kümmel. 1998. Influence of sediment removal on fishpond phytoplankton. Algological Studies, 89: 107-120.

Ruhí, A., D. Boix, J. Sala, S. Gascón \& X.D. Quintana. 2009. Spatial and temporal patterns of pioneer macrofauna in re- cently created ponds: taxonomic and functional approaches. Hydrobiologia, 634: 137-151.

Schenková, J., J. Sychra, V. Košel, N. Kubová \& J. Horecký. 2009. Freshwater leeches (Annelida: Clitellata: Hirudinida) of the Czech Republic (Central Europe): checklist, new records, and remarks on species distributions. Zootaxa, 2227: 32-52.

Solimini, A.G., A. Ruggiero, V. Bernardini \& G. Carchini. 2003. Temporal pattern of macroinvertebrate diversity and production in a new man made shallow lake. Hydrobiologia, 506-509: 373-379.

Søndergaard, M., E. Jeppesen, J.P. Jensen \& T. Lauridsen. 2000. Lake restoration in Denmark. Lake Reserv. Manage., 5: 151-159.

Sychra, J. \& Z. Adámek. 2010. Sampling efficiency of Gerking sampler and sweep net in pond emergent littoral macrophyte beds - a pilot study. Turkish Journal of Fisheries and Aquatic Sciences, 10: 161-167.

ter Braak, C.J.F. \& P. Smilauer. 2002. CANOCO Reference Manual and CanoDraw for Windows User's Guide: Software for Canonical Community Ordination (version 4.5). Ithaca, NY, USA (www.canoco.com): Microcomputer Power.

Tugend, K.I. \& M.S. Allen. 2004. Changes in the plant and fish communities in enhanced littoral areas of Lake Kissimmee, Florida, following a habitat enhancement. Lake Reserv. Manage., 20: 54-61.

Van Wichelen, J., S. Declerck, K. Muylaert, I. Hoste, V. Geenens, J. Vandekerkhove, E. Michels, N. De Pauw, M. Hoffmann, L. De Meester \& W. Vyverman. 2007. The importance of drawdown and sediment removal for the restoration of the eutrophied shallow Lake Kraenepoel (Belgium). Hydrobiologia, 584: 291-303.

Ward, J.V. 1992. Aquatic Insect Ecology. 1. Biology and Habitat. John Wiley \& Sons, Inc., New York, Chichester, Brisbane, Toronto, Singapore: $456 \mathrm{pp}$.

Yuvanatemiya, V. \& C.E. Boyd. 2006. Physical and chemical changes in aquaculture pond bottom soil resulting from sediment removal. Aquacult. Eng., 35: 199-206.

Zákravský, P. \& Z. Hroudová. 2007. Vliv řízeného rybničního managementu na obnovu rákosin v NPR Velký a Malý Tisý. [The influence of controlled fishpond management on reed-bed restoration in the Velký a Malý Tisý National Nature Reserve.] Zprávy Čes. Bot. Společ., Praha, 42, Mater., 22: 167-196. [in Czech]

\section{A P P E N D I X}

Macroinvertebrate taxa and number of individuals captured at the Štěpánek fishpond between 2003 and 2008 (species codes as used in Fig. 4).

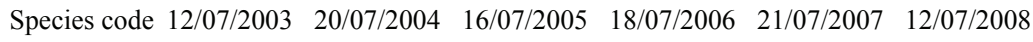

\section{Gastropoda}

Lymnaea stagnalis (Linnaeus, 1758)

Radix auricularia (Linnaeus, 1758)

Gyraulus albus (O.F. Müller, 1774)

Gyraulus crista (Linnaeus, 1758)

Hippeutis complanatus (Linnaeus, 1758)

Oligochaeta

Ophidonais serpentina (Müller, 1774)

Stylaria lacustris (Linnaeus, 1767)

Dero digitata (Müller, 1774)

Nais variabilis Piguet, 1906

Slavina appendiculata (Udekem, 1855)

Limnodrilus sp.

$\begin{array}{ccccc} & & & & \\ \text { RadAur } & 1 & & & \\ \text { GyrAlb } & 221 & 4 & 4 & 4 \\ \text { GyrCri } & 23 & 1 & 21 & 2 \\ & & & & \\ \text { OphSer } & & 27 & 124 & 43 \\ \text { StyLac } & 201 & 5 & 14 & 368 \\ \text { DerDig } & 136 & 14 & 6 & 10 \\ \text { SlaApp } & & & 7 & \\ \text { Limnodr } & 2 & 3 & & \end{array}$

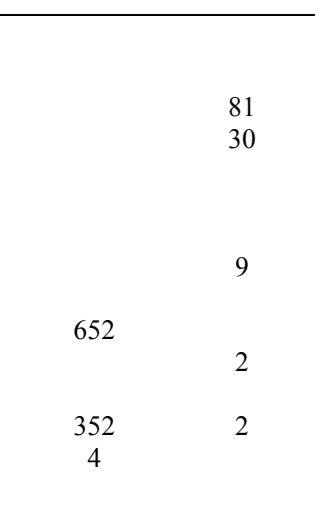

Limnodrilus hoffmeisteri Claparede, 1862

Limnodrilus udekemianus Claparede, 1862 
Appendix. Continuation.

\begin{tabular}{|c|c|c|c|c|c|c|c|}
\hline & Species code & $12 / 07 / 2003$ & $20 / 07 / 2004$ & $16 / 07 / 2005$ & $18 / 07 / 2006$ & $21 / 07 / 2007$ & $12 / 07 / 2008$ \\
\hline Tubificidae gen. sp. juv. & Tubific & 6 & & & & 36 & \\
\hline Aulodrilus pigueti Kowalewski, 1914 & & & & & & 4 & \\
\hline Cognettia sphagnetorum (Vejdovský, 1878) & & & & & 8 & & \\
\hline Lumbriculus variegatus (Müller, 1774) & & & 6 & & & & \\
\hline \multicolumn{8}{|l|}{ Hirudinida } \\
\hline Theromyzon tessulatum (O.F. Müller, 1774) & & 4 & & & & & 2 \\
\hline Hemiclepsis marginata (O.F. Müller, 1774) & HemMar & 105 & & & & & \\
\hline Alboglossiphonia hyalina (O.F. Müller, 1774) & & & & & 2 & & \\
\hline Helobdella stagnalis (Linnaeus, 1758) & HelSta & 213 & & 3 & 88 & 8 & 3 \\
\hline Piscicola geometra (Linnaeus, 1758) & & 3 & & & 4 & & 1 \\
\hline Erpobdella octoculata (Linnaeus, 1758) & ErpOct & 52 & 1 & 3 & 60 & & \\
\hline \multicolumn{8}{|l|}{ Crustacea } \\
\hline Argulus foliaceus (Linnaeus, 1758) & & & & & 2 & & \\
\hline \multicolumn{8}{|l|}{ Acari } \\
\hline Hydrachnellae gen. sp. & Hydrach & 22 & 10 & 212 & 334 & 4 & 66 \\
\hline \multicolumn{8}{|l|}{ Ephemeroptera } \\
\hline Cloeon dipterum (Linnaeus, 1761) & CloDip & 1893 & 4 & 15 & 324 & & 255 \\
\hline Caenis sp. & Caenis & 22 & 6 & 4 & 68 & & 17 \\
\hline \multicolumn{8}{|l|}{ Heteroptera } \\
\hline Ilyocoris cimicoides (Linnaeus, 1758) & & & & & 2 & & \\
\hline Notonecta glauca Linnaeus, 1758 & & & & & & & 2 \\
\hline Notonecta viridis Delcourt, 1909 & & & & & & & 17 \\
\hline Notonecta sp. juv. & & 2 & & & & & 5 \\
\hline Plea minutissima Leach, 1817 & & 1 & & 1 & 2 & & \\
\hline Micronecta scholtzi (Fieber, 1860) & MicSch & & & & & 10 & 216 \\
\hline Sigara lateralis (Leach, 1817) & SigLat & & & & & 460 & 13 \\
\hline Sigara falleni (Fieber, 1848) & SigFal & 11 & 9 & & & 6 & 60 \\
\hline Sigara striata (Linnaeus, 1758) & & 7 & 1 & & 6 & & \\
\hline Paracorixa concinna (Fieber, 1848) & & & 1 & & & 8 & \\
\hline Callicorixa praeusta (Fieber, 1848) & & & & & & & 2 \\
\hline Corixinae gen. sp. juv. & Corixinae & 404 & 4 & 10 & 226 & 304 & 29 \\
\hline Gerris lacustris (Linnaeus, 1758) & & & & & & & 1 \\
\hline Gerris odontogaster (Zetterstedt, 1828) & & 5 & & 1 & 2 & & \\
\hline Gerris sp. juv. & & & & 1 & 2 & & 2 \\
\hline \multicolumn{8}{|l|}{ Megaloptera } \\
\hline Sialis lutaria (Linnaeus, 1758) & & 1 & & & 2 & & \\
\hline \multicolumn{8}{|l|}{ Odonata } \\
\hline Platycnemis pennipes (Pallas, 1771) & & 4 & & & & & \\
\hline Coenagrion sp. & & & & & 6 & & 17 \\
\hline Ischnura elegans (Vander Linden, 1820) & IschEle & 15 & & 10 & 5 & & 12 \\
\hline Libellula depressa Linnaeus, 1758 & & & 1 & & & & 1 \\
\hline \multicolumn{8}{|l|}{ Coleoptera } \\
\hline Haliplus fluviatilis Aubé, 1836 & & & & & & & 1 \\
\hline Haliplus sp. juv. & & 2 & 3 & & & & 6 \\
\hline Noterus crassicornis (O.F. Müller, 1776) & & & & 6 & 2 & & 1 \\
\hline Noterus sp. juv. & & 3 & & & & & \\
\hline Laccophilus minutus (Linnaeus, 1758) & & & & & & & 1 \\
\hline Rhantus frontalis (Marsham, 1802) & & & & & & & 1 \\
\hline Graphoderus sp. juv. & & 1 & & & & & 1 \\
\hline Helophorus granularis (Linnaeus, 1761) & & 1 & & & & & 2 \\
\hline Coelostoma orbiculare (Fabricius, 1775) & & & & & & & 1 \\
\hline Anacaena lutescens (Stephens, 1829) & & & & & & & 1 \\
\hline Laccobius sp. juv. & & & & & & 4 & \\
\hline Enochrus sp. juv. & & & & & 2 & & \\
\hline Hydrobius fuscipes (Linnaeus, 1758) juv. & & & & & & & 1 \\
\hline Hydrophilus sp. juv. & & 1 & & & & & \\
\hline \multicolumn{8}{|l|}{ Lepidoptera } \\
\hline Cataclysta lemnata (Linnaeus, 1758) & & 2 & & & 8 & & \\
\hline \multicolumn{8}{|l|}{ Chironomidae } \\
\hline Camptochironomus gr. tentans Fabricius, 1805 & & 6 & & 2 & & 4 & \\
\hline Cladotanytarsus sp. & & & & & & & 1 \\
\hline Clinotanypus nervosus (Meigen, 1818) & & & 1 & & & & \\
\hline Corynoneura gr. scutellata Winnertz, 1846 & $\mathrm{CorScu}$ & & & 94 & & & 1 \\
\hline Corynoneura sp. & & & 1 & & 1 & & \\
\hline
\end{tabular}

(continued) 
Appendix. Continuation.

\begin{tabular}{|c|c|c|c|c|c|c|c|}
\hline & Species code & $12 / 07 / 2003$ & $20 / 07 / 2004$ & $16 / 07 / 2005$ & $18 / 07 / 2006$ & $21 / 07 / 2007$ & $12 / 07 / 2008$ \\
\hline Cricotopus gr. sylvestris (Fabricius, 1794) & CriSyl & 2 & 10 & 176 & 91 & & 274 \\
\hline Cryptochironomus sp. & & & 1 & 2 & & & \\
\hline Dicrotendipes sp. & & & & & & & 4 \\
\hline Endochironomus sp. & & 1 & & 10 & 4 & & 1 \\
\hline Glyptotendipes sp. & Glypto & 84 & 13 & 112 & 106 & & 28 \\
\hline Chironominae sp. juv. & & & & & & 2 & \\
\hline Chironomus plumosus (Linnaeus, 1758) & & 6 & & & & & \\
\hline Metriocnemus cf. & & & & & & & 1 \\
\hline Microtendipes gr. chloris (Meigen, 1818) & MicChlo & 1 & 101 & 52 & 8 & & \\
\hline Nanocladius cf. bicolor Zetterstedt, 1838 & & & & & 2 & & \\
\hline Parachironomus sp. & & & 2 & & 9 & & 1 \\
\hline Polypedilum gr. nubeculosum (Meigen, 1804) & & & 18 & 2 & & & 5 \\
\hline Polypedilum sp. & & & & & 1 & & \\
\hline Procladius (Holotanypus) sp. & Proclad & 4 & 67 & & & 36 & \\
\hline Tanypodinae sp. juv. & & 7 & & & & 2 & \\
\hline Tanypus kraatzi (Kieffer, 1912) & & 2 & & & 1 & 20 & 4 \\
\hline Tanypus punctipennis Meigen, 1818 & TanPun & & 13 & & & 148 & 1 \\
\hline Tanytarsus sp. & & & 1 & & & & \\
\hline Thienemannimyia gr. & & & & 1 & & & \\
\hline $\begin{array}{l}\text { Xenopelopia sp. } \\
\text { other Diptera }\end{array}$ & & 7 & & & 1 & & 1 \\
\hline Dixella amphibia (De Geer, 1776) & & & & 11 & & & 1 \\
\hline Chaoborus crystallinus (De Geer, 1776) & & 7 & & 7 & & & \\
\hline Ceratopogonidae gen. sp. juv. & & & 1 & 2 & & 4 & \\
\hline Anopheles gr. maculipennis Meigen, 1818 & & & & & & & 2 \\
\hline Culex modestus Ficalbi, 1890 & & & & & 8 & & \\
\hline Culex sp. juv. & & & & & 12 & & \\
\hline Scaptomyza sp. & & & 1 & & & & \\
\hline Muscidae gen. sp. juv. & & & 1 & & & & \\
\hline Paramormia sp. & & & & & & 4 & \\
\hline Odontomyia sp. & & & & 4 & & & \\
\hline Stratiomyidae gen. sp. juv. & & 5 & & 1 & & & \\
\hline Sciomyzidae gen. sp. juv. & & 1 & & 1 & 2 & & \\
\hline
\end{tabular}

Received: October 2010

Accepted: December 2010 